Predrag Ubavić, $\mathrm{PhD}^{1}$

A.D. „Planinka“ - Kursumlija
SCIENTIFIC REVIEW ARTICLE

Received: January 21, 2015

Accepted: February 17, 2015

\title{
INFORMATIONAL RESOURCES MANAGEMENT IN TOURISM
}

\begin{abstract}
Every field of people's conscientious act require making corresponding decisions. Since making right and timely decisions requires certain information, that can also be applied for making decisions in tourism business. Tourism is a heterogeneous activity, which create numerous opportunities for general and specific implementation of different information. Therefore, the subject of this paper's analyse is necessary information for making timely and right decisions in the tourism business, as well as the manner of collecting the same. The aim of this paper is to point the importance of information management, as a crucial resource in tourist enterprises, on which depends right and timely making decisions by the management of those enterprises.
\end{abstract}

Key words: management, information, informational resources, tourism.

JEL Classification: L83, D83, M15

\section{УПРАВЉАЊЕ ИНФОРМАЦИОНИМ РЕСУРСИМА У ТУРИЗМУ}

\begin{abstract}
Апстракт
Свака област свесног људског деловања захтева доношење одговарајућих одлука. Како су за доношење исправних и благовремених одлука потребне одређене информације, то се исто може рећи и за доношење одлука у обављаюу туристичке делатности. Туризам је хетерогена делатност, ито ствара бројне могућности за општу и специфичну примену различитих информаџија. Дакле, предмет анализе овог рада су неопхоне информаџије за доношене правовремених и исправних одлука у туристичкој делатности, као и начини прикупљања истих. Циљ овог рада је да укаже на значај управљања информацијама, као битним ресурсом у туристичким предузећима, од кога зависи исправно и благовремено доношење одлука од стране менаимента тих предузећа.
\end{abstract}

Кључне речи: управљање, информације, информациони ресурси, туризам.

${ }^{1}$ p.ubavic@gmail.com 


\section{Introduction}

Contemporary economy subjects, among which are those from tourism field, do the business in the conditions of intensive changes of business surrounding what requires their adjustment to newly conditions. Dynamism of economic environment on principles of market based business establishes a business philosophy which will be based on requests, not only strategic marketing, but also strategic management. One of the important assumptions for efficient functionality of an enterprise is existing adequate informational system, which will ensure aquiring and data analyse, their translation into information and their presentation to the users, e.g. management.

In professional literature, especially about the management of informational systems, there is a difference between the terms „data“ and „information“. Data are usually defined as registered facts refering to individual aspects of functioning studied system. Information is processed data, e.g. data which have specific meaning.

Relation between data and information is treated as well as relation between raw material (input) and final products (output), and data processing (application of certain operations on data) is deemed as a way of information production.

Therefore, information is not just data, but it is obtained by facts analyse and recognizing the message which comes out from data analyse. While data are unvalued messages, information is improved with message on a specific situation, or knowledge used by those who make decisions e.g. managers.

Information affect quality of business decisions which initiate activities, so though it they direct success or failure in company's business. Therefore information is treated as some resource which companies use in accomplishing their mission.

\section{Informational base of strategic process of making decisions in tourism}

As reasons for which information will have to become a base of majority of companies can be named the following: (1) is shown in demographic indicators, where educated workers are not the subject to command-and-control methods of the past; (2) is shown in necessity for systematization of innovation and entrepreneurship; (3) is that companies should comply with information technology (Drucker, 1995). Each individual company must decide what information is needed to run a business, because otherwise they will "drawn" in loads of data and information. Information becomes useful for communication in case the receiver adapts and understands it.

The concept of information has more dimensions. "Emphasising the importance of strategic process of making decisions, a lot of authors observe information as "a system of knowledge" or "the base of knowledge", or such information is called "soft". Such information is usually external and relate to future". This kind of information is suitable for descriptive or ideographic presentation. "Conversely, "hard" information can be quantitatively expressed and processed by using different analythical methods" (Radosavljević, 2002, p. 53).

Numerous surveys have shown that "hard" information is not necessary in strategic process of making decisions, but it is significant for business survey of the company 
in the previous period of time, can be easily collected, systematised used as a base to foresee the future. The importance of "soft" information and their usage in strategic process of making decisions is widely known, because unstructured issues is very rarely possible to solve just by collecting and analysing "hard" data. The grade of "hard" and "soft" information depend on the type of strategic action and the phase of the strategic process of making decisions (Radosavljević, 2002).

When it is about tourist companies, for strategic positioning of their products and services on the tourist market, especially are important such information on expectancy and tourists' behaviour. Timely information are necessary about the number of tourists, average length of their stay, their purchasing power, affinity to consumption, their educational, sex, age and other structure.

Tourism and other economic activities, are still not sufficiently able to use all advantages of GIS (Geographic information systems) technology. Although, GIS (Geographic information systems) is present for almost forty years, the most frequent use is recorded in the last ten years. "Geographic information systems, as a rationally organized collection of computer hardware, software, geographic data and users, enable the effective collection, storage, sorting, manipulation, analysis and spatial display of geographic information that are of interest for the user" (Seferović \& Stankov, 2009, p. 117).

Before making a decision about the way to gather wanted information, it is necessary to analyse the value of such information. If it is estimated that such information will have a positive effect on business activity of a concrete tourist company, it is necessary to realize the relation between the effects which are achieved by using such information and costs of their collecting.

Each company before the process of collecting data should consider three questions: (1) a possibility of getting required information; (2) expenses of collecting information and (3) contribution of information to more effective process of making decisions (Walters, 1989).

As the level of making decisions is increased, from operative, through tactic to strategic, that's the way the scope of external information is increased, and internal decreased. It is similar with the levels of management at a company. Basic characteristics of information necessary for operative management are: intern origin, details, time continuity, high structuralism and accuracy, whereas for strategic management needed such information directed to future, unprogrammed, of external character, general, periodical and less precise.

It is essential to point out that abundance of information does not necessarily consider their quality. The quality of information is affected by following their characteristics: relevance, accuracy, usefulness, comprehensiveness, timeliness, credibility etc. By relevance it is consider that information managers get must have relevance for their authority and activities they deal with. Accuracy and information usefulness go together. Useful is that information which leads to successful making decisions. The information meets criteria of accuracy in case managers know how to use it. Credibility of information is improved by planning the approach to survey, as well as usage of services of survey of external institutions. It is necessary to plan the system of information in such a way, so that reports are uniformed, uniquely and concretely presented to users. The quality of information, also depend on their timeliness, because for making adequate business decisions right information is needed, at the right time and the right place. 
It has already been pointed out that one of the basic characteristics of strategic process of making decisions is their primarily external orientation, e.g. aim at establishing corresponding relation between company and environment. Due to the fact that marketing, as a business conception and philosophy of economy by its essence externally orientated, therefore its role in the process of strategic management and making decisions makes it especially significant. In addition to that, the task of marketing surveys, in tourist companies, is to provide such information base on needs and wishes of consumers/tourists which will help to realize the decisions of tourist companies in the most appropriate way from the point of view of their mission and long--term business goals.

However, marketing survey should not exist isolated as the only way of data collection. Marketing should, first of all, be considered as a part of systematic and continuous effort of a tourist company to improve its process of making decisions. It is important to point out that marketing survey is significant from the aspect of information contents and the manner of their collection, and company's informational system refers to flow of information management from different sources of data to managers who will use them. "That requires a data base for organizing and information storage and support system for making decisions transfering data into useful information and their deliverance to users" (Aaker, Kumar \& Day, 1995, p. 23).

In modern tourism business relation between producers/offers and customers/ tourists has fundamentally changed, it is being more and more conducted without mediators, customers' and offers' needs are met in decreased timeframe, costs are reduced etc. "The development of information technologies and Internet has influenced the emergence of digital economy, which is based on development and usage of new organizational models, new products and services, behavior rules, and the new way of business thinking" (Rodić, Mitrović \& Mitrović, 2012, p. 447).

All information necessary for tourist company's function should be stored in control information centre for future and present usage, and the control centre itself should be integrated into short-term and long-term planning and company's functioning. Informational system of a tourist company set in this way in most cases is called integral informational system, which is based on integration and gathering all data in data base, as well as integration of communication process with the process of data base and process of making decisions.

Modern tourist business is constantly under the influence of different factors in the business environment. However, most of the activities in tourism enterprises can be significantly facilitated by information and communication technology. "It is important that the management company designate adequate information technology and recognize its impact on the organization and structure of the company" (Muhović \& Ćurčić, 2011, p. 173).

Development of marketing survey in direction of marketing informational systems enabled (Hanić, 1996):

- Marketing surveys to orientate on necessities of marketing management for information,

- Collecting external information to be done continuously and

- To organize total informational activities in marketing. 


\section{Marketing informational system (MIS) in tourism}

Appropriate obtain of information, necessary for marketing making decisions, requires existance of correpsonding system for continuous collecting, analyse and presenting data-information. That makes the essence of marketing informational system, defined as ,continuous and intractive structure of people, equipment and procedures with the aim of collecting, classification, analyze, estimation and distribution of adequate, timely and accurate information" which will be used by those responsible for making decisions in marketing in order to improve marketing of planning, performing and control (Kotler, 1986, p. 86).

Marketing informational system (MIS) fulfills the function within its four subsystems (Kotler, 1986):

- Intern system of information,

- System of marketing information,

- System of marketing survey and

- Analytical marketing system.

Intern system of information, e.g. intern accountancy system presents data on existing sales, expenses, the flow of ready money, as well on status of debt and company's liabilities. System of marketing information presents a set of sources and procedures by which marketing sector gets daily information on events in environment. The sources of information can be named: tourist intermediaries, channels of tourist products and services distribution, organizations which professionally deal with surveys etc. Marketing research is systematic way of collecting, analyze and distribution of data and certain knowledge relevant for specific marketing situations a company faces with. Analytical marketing system consists of technics for analyses marketing data and issues. Its integral parts are (base) statistic data bank and patterns bank. Base of statistic data make total statistic data which are necessary in marketing function. Patterns bank consists of modern mathematical patterns used to make adequate and timely decisions.

Informational systems, including MIS, can exist in various forms, depending on their scope and purpose. As phases in informational systems development can be named the following (Popesku, 2002):

- Data Processing - collecting basic data and making a report;

- Management Information Systems - data processing and providing information which help management in the process of making decisions;

- Decision Support Systems (DSS) - interaction with decision makers in their decision-making process;

- Expert Systems - use expert knowledge to solve insufficiently structured problems on the basis of connecting to databases;

- Executive Information Systems - connect possibilities of DSS and expert systems.

The structure of managing informational systems in tourism, both in macro, as well as micro level, must show the nature of process of making decisions. The uniqueness of management in tourism requires a process of making decisions to be considered in relation to the following their dimensions (Popesku, 2002): 
- The level of aggregating on which decisions are made,

- Included other economy branches and activities,

- $\quad$ Phase of management process,

- $\quad$ Relation between the level of management and making decisions and

- $\quad$ Functional field of making decisions.

Creating marketing informational system, with an aim of systematic support for the needs of managers in tourism, is a very complex and long-term process. Within that process is almost impossible to expect certain results for relatively short time period.

Marketing informational systems can be developed as "ad hoc" or as completely integrated systems. In the first case, they are developed according to experience, what makes a basic drawback of this approach - number of compromises it is subjected to. Other approach mean strictly planned and integrated system, which is included in the organizational structure of the company and in whose creation are included those for whom information are intended - those who make decisions. Other approach in making marketing informational system is harder, and in its base it is more appropriate, because it involves planned approach and efficiently creation a relation between the system and its users.

As a separate important issue, while creating marketing informational systems in tourist companies, appears their connection with marketing informational system on a macro level. In the mentioned context it is extremely important to point out the reasons which show the necessity of marketing information management and development of marketing information systems of these companies (Hanić, 2001):

- Informational explosion,

- Increasing complexity of jobs and company's environment,

- Company's growth,

- Increase of making decisions' process,

- Application of patterns in marketing management,

- Using the advantage of modern informational technology,

- Increase of information number within time unit,

- Achievement of the same level of content with informational needs with fewer expenses,

- Uniforming the information distributed to various parts of the company into a sensible whole,

- Providing conditions for effective application of marketing conception,

- Faster recognition of trends in company's environment,

- Increase of analytical power and total efficiency of marketing,

- Possibility to make optimal decisions,

- Better control of carrying out marketing plans and actions etc.

The efficiency of marketing management activity of tourist companies is conditioned by the system of communication, or organizing information course. In the system of communication one should make a difference between three basic information courses, such as:

- Input information,

- Intern course of information and

- $\quad$ Output information. 
Input information comes from the surrounding in which a company deals with its business activity. In tourist companies these are, first of all, information from tourists, then information from tourist agencies, other intermediaries, competition companies, state organs and institutions etc. Intern course of information is carried out within the company itself. Such information come from different departments at a company, which are obliged to collect information and analyze them connected to marketing. Output information included in messages a company sends to its present and potential customers/ tourists, various institutions, publicity etc.

The success of tourist company's business activity first of all depends on efficiency of its informational system. Marketing department in a tourist company monitors the situation on the tourist market (input information), prepares with other departments at the company to meet the observed requirements of the customers /tourists (intern course of information) and tourist products/services are presented on tourist market about what the company informs the customers of its products /services (output course of information).

Today's dynamic business environment defines the conditions in the direction of creating a high degree of flexibility. Also, we are conforted with changes in the value system of customers and with the need for developing good, long-termed relationships with them. "In these activities, special emphasis should be put on attraction of new customers and maintaining good relation with the existing ones. Therefore, ranges of available information technologies should be maximized in creating an efficient communication with customers, but also with all other participants in the market" (Ratković \& Grubić, 2011, pp. 67-68).

As a very important fact, in the process of making right and timely marketing decisions at a tourist company, there is knowledge e.g. ability of the one who makes decisions to use the information received from marketing informational system (MIS). In that sense adequate and professional personnel should be employed on marketing jobs, because their job is not only to make certain decisions, but necessity to recognize specific marketing issues.

Considering their uniqueness marketing decisions can always contain certain level of risk, therefore they can almost never be optimal and best, but always tend to be on a higher level of quality, because of what they will be better if the quality of marketing informational system (MIS) and its information adjust to the quality of making decisions.

Therefore, from the right comprehension and connection of all elements of marketing informational system (MIS) at a tourist company, depends in a great deal the quality of information and the level of their usage for making even better marketing decisions. That basically mean creation of more certain and safer future through the decisions which are made in the present.

\section{Researching tourist market as a way of collecting information in tourism}

Fast and tumultuous development of tourism imposed a necessity to research tourist market. There is a clear difference between research of tourist market and marketing research. Market research is a narrower idea in relation to marketing research. According to one of widely accepted definitions, the research of tourist market includes 
"...collecting, registration and analysis of all issues with tourist market, an aim to determine past, present, possible and future service users" (Stefanović \& Gligorijević, 2010, p. 151).

As special fields of tourist market research can be named the following (Unković \& Zečević, 2011):

- Determination of present and potential tourist requirements,

- Research of present and potential demand,

- Determination of present and potential tourist consumption,

- Research of adequate tourist offer,

- Research of possibilities to improve tourism and

- Determination of tourist services' prices.

Analyse of information collected from tourist market should answer the questions such as: who, how, why, when and to whom should be offered certain services on observed market?

There are two basic approaches to tourist market research: macro and micro approach. Macro researches of tourist market are dealt with on the level of certain countries, regions or tourist resorts. Such researches present a foundation to determine and lead tourist politics, e.g. to formulate long-term approach to tourism development. Dealing with jobs in tourist market research on macro level is done by national tourist organizations in cooperation with regional and local tourist organizations. Basic field of interest of these researches is analysis of demand and offer on tourist market. Researches on macro levels are done by concrete companies in tourist economy. Micro analysis starts with the results gained by macro research and they are focused on leading business politics of these companies. In micro analysis of tourist market research, a special attention is also paid to competition research e.g. their abilities and opportunities.

Researching the tourist market enables to define more precisely requirements, motives and tourist behaviour, in order to realise whether there is and in what amount a demand for products/services of a tourist company. "The final objective of the tourist market research is to obtain information according to which the management of a tourist company will make adequate business decisions referring to solving concrete business issues, what will decrease the business risk to some reasonable scope" (Ubavić, 2012, pp. 43-44).

The process of tourist market research itself consists of three basic phases: (1) preparation; (2) research in narrower sense and (3) results application.

Within the preparation an initiative is established to research the market. Research in narrower sense includes: situation analysis, setting of various hypothesis, research plan, data collecting and registration, data processing and analysis, interpretation and making reports for research users. Within the phase of preparation, application of research results is monitored.

By its importance especially is distinguished a phase in which data are collected. All data sources related to a tourist market can be separated into four basic groups: (1) data in the company e.g. place of research; (2) official (statistical) data; (3) unofficial data and (4) data from specially organized surveys or other forms of immediate research.

First three, previous, mentioned sources of data are named as secondary data sources, while the fourth data source is named terrain and it is used to collect primary 
data, which are harder for collecting and at the same time more expensive.

Connected to a tourist market research a special attention should pay to selection of research methods. At the base of this all methods of tourist market research can be separated into two basic groups (Unković \& Zečević, 2011):

- Quantitative (based on mathematical-statistical instruments) and

- Qualitative (based on psychological-qualitative technique).

Quantitative methods are based, both on secondary and primary data sources. Within the group of quantitative methods of tourist market research can be also named several sub-groups (Stefanović \& Gligorijević, 2010):

- Historical methods,

- Methods of examination (sondage) and

- Experimental method.

Historical methods or methods of direct data mainly include statistical methods (average value, indexes, trend, regressional and correlational analysis etc.), then gravitational model and model of market segments. Statistical methods found its widest application in average-term and long-term projections of tourism development. Gravitational model is based on correlational and regressional analysis. In this model construction an important role plays elasticity of some phenomenon which is being researched. As a major issue in gravitational model appears to be finding regressional line which can have a form of a straight line, parabola, logistic curve, exponential function etc. Models of market segments start from previously given quantative indicators for forming tourist segments of foreign and domestic tourists.

Sondage as a method of tourist market research is based on primary sources of information. The base of this method presents a sample. In tourist market research most applied is multiple-level sample, stratified sample and multiple-phase sample.

Experimental method is used to obtain information according to experimental observation. This method base is made of examination and checking of set hypotheses. In observation of a certain phenomenon two groups are taken, of which one is experimental and is exposed to a required factor affect, while the other group is chosen by the principle of random from the same mass and it is not exposed to required factor affect. This method is suitable for example to determine effects of tourist propaganda.

Qualitative methods of tourist market research are based on application of psychology and are mainly oriented on research of travel motives and attitudes or opinions of tourists. Among qualitative methods can be named the following:

- Thorough interview,

- Technique so called ,third person“,

- Technique of completing sentences,

- Association tests on given words and

- Prejection technique.

Among the qualitative methods, a thorough interview has the widest usage. In this interview there is a sincere and thorough conversation with a group of 50 to 200 people, usually individually, and in certain cases in the group as well. Interviewees are asked direct and indirect questions. It is necessary to relieve from their conversations either conscious or unconscious motives of their behaviour. 
As a basic problem in qualitative methods of tourist market research there is a readiness for cooperation of all persons who are supposed to be interviewed. In accordance to this there can be the following situations: (1) asked information is known to the interviewed person and she is ready to announce it; (2) asked information is known to the interviewed person, but she is not ready to announce it directly; (3) asked information can be obtained from the interviewed person, but she is not capable to describe it or express directly and (4) asked information on present ot potential interviewees can be obtained only by observing them by the researcher.

If we observe advantages and disadvantages of quantitative and qualitative methods of tourist market research, it can be said that the advantage of quantitative method is that results can be expressed numerically, what represents an important quality in the sense of exactness. Usage of qualitative methods requires more effort, however by applying them some general and essential data can be gained. From that reason it is recommeneded a combination of quantitative and qualitative methods what can enable achievement of numerical expression of quantitative research results, and that is a condition to expand usage of qualitative methods and at the same time gaining more qualitative reserach results.

\section{Conclusion}

As in other economy activities, also in tourism, for a direct business activity certain resources are needed. Besides material, financial and human resources, informational resources are also necessary, or information, in accordance to which managers in tourist companies will make adequate and timely business decisions. In order to collect the necessary information for management and making decisions in every company, and also in a tourist company, it is essential to have a plan of collecting, processing and analysing such information. Company's management should initiate influx of required and qualitative information, and for that it is necessary to have an adequate informational system, as well as professional personnel who will deal with selection and data processing and their presentation to responsible managers.

In modern business conditions the importance and role of marketing is indefinite and informational system marketing (MIS) in collecting, processing and analysing of information from the company's surrounding. On the other hand, every tourist company which runs a business on a profitable base, must organize market research, both domestic and regional and international, in order to be in touch with contemporary phenomena and movements on them.

Developing modern informational systems along with support of information technology, strategical management of tourist company becomes more reliable and flexible, what essentially increases its competition ability. A range of changes of intern and extern character, which follow business in modern tourism, caused expansion in informational technology (IT) application. Therefore, complete and efficient plan of using informational systems and information technology in a tourist company requires a systematic approach, creative thinking, serious analysis, investing material and other resources, a different profile team experts, as well as efficient intern organization along with full management support. 


\section{References}

Aaker, D. A., Kumar, V. \& Day, S. G. (1995). Marketing Research. 5th edition. John Wiley \& Sons. Inc. New York.

Drucker, F. P. (1995). Menadžment za budućnost. Grmeč. Beograd.

Hanić, H. (1996). Marketinški informacioni sistemi: za menadžere. Ekonomski fakultet. Beograd.

Hanić, H. (2001). Istraživanje marketinga i marketing informacioni sistemi. Ekonomski fakultet. Beograd.

Kotler, P. (1986). Principles of Marketing. 3rd edition. Prentice Hall International. Englewood Cliffs. New Jersey.

Muhović, A. \& Ćurčić, N. (2011). Informaciona tehnologija u savremenoj organizaciji. Ekonomika, 57(4), 173-182.

Popesku, J. (2002). Marketing u turizmu. Čigoja štampa \& CEORT. Beograd.

Radosavljević, G. (2002). Informacioni sistem za upravljanje trgovinskim preduzećem. Ekonomski fakultet. Kragujevac.

Ratković, M. \& Grubić, G. (2011). Promene u marketingu usled primene savremenih informacionih tehnologija. Ekonomika, 57(1), 67-79.

Rodić, B., Mitrović, M. \& Mitrović, U. (2012). Marketing u uslovima digitalne ekonomije i elektronskog poslovanja. Ekonomski vidici, 17(3), 437-447.

Seferović, S. \& Stankov, U. (2009). Opšta i specifična upotreba geografskih informacionih sistema u turizmu. Zbornik radova Departmana za geografiju, turizam i hotelijerstvo, 38, 117-127. Prirodno-matematički fakultet. Novi Sad.

Stefanović, V. \& Gligorijević, Ž. (2010). Ekonomika turizma. Sven. Niš.

Ubavić, P. (2012). Istraživanje turističkog tržišta. BizInfo, 5, 43-52.

Unković, S. \& Zečević, B. (2011). Ekonomika turizma. 22. izdanje. Ekonomski fakultet. Beograd.

Walters, D. (1989). Strategic Retailing Management - A Case Study Approach. Prentice Hall. London. 